\title{
MICROSTRUCTURAL FINITE STRAIN ANALYSIS OF THE HAFAFIT GRANITOIDS DOMES SOUTH CENTRAL EASTERN DESERT OF EGYPT
}

\author{
Thabet I. $^{1 \& 2}$, Kilias A. ${ }^{2}$ and Kamh S. ${ }^{1}$ \\ ${ }^{I}$ Geology Department, Faculty of Science Tanta University, Tanta, Egypt, \\ eslam642004@yahoo.com.,kilias@geo.auth.gr,kamh2002@yahoo.com. \\ ${ }^{2}$ Geology and Palaeontology Department, School of Geology, Aristotle University of Thessaloniki,
} Greece.

\begin{abstract}
The Wadi Hafafit Culmination (WHC) can be subdivided into two main units which are separated by Nugrus thrust shear zone. The WHC domes are occupies the southern part of the Central Eastern Desert of Egypt and is cored by five separated gneissic granitoids ranging in composition from tonalite to granodiorite having compositions consistent with hydrous partial melting of a mafic source suggesting subduction-related magmatism. The leucogranites along thrust zones is related to the late phase of metamorphism of Hafafit rocks. The five main domes of the WHC have been labeled A dome occupies the northern part of WHC, B and C domes occupies the central eastern part of WHC, D dome occupies the central western part of WHC and E dome occupies the southern part of WHC. The fourth domes A, B, C and $E$ are affected by more than one deformation event but $D$ dome is affected by one deformation event. The domes not uniform throughout the WHC according radial pattern of stretching lineation but these domes of WHC were subjected and affected by late-orogenic extension that was controlled by the Najd transform faults and that resulted in exhumation of the WHC domes are oriented NW-SE parallel to the trend of the left-lateral shear zones of Najd fault system.

Key words: Wadi Hafafit Culmination, Strain analysis, Deformations, Najd fault.
\end{abstract}

\section{Introduction}

Some of the most conspicuous Precambrian structures in the Eastern Desert of Egypt are met with in the Migif-Hafafit area. This area is characterized by huge open regional folds trending NW-SE. The WHC has been studied by El Ramly etal. (1984) as part of a collaborative project between the Geological Survey of Egypt and University of Mainz, West Germany. This study was based essentially on the detailed lithological field mapping of this area by El Ramly in the late fifties together with photo-interpretation. The most spectacular antiform is a structural culmination composed of several granitoid-cored gneiss domes. These domes is raced for about $55 \mathrm{~km}$ from Wadi Shait in the north to Wadi El Gemal in the south. The WHC is bordered in the east by the Hangaliya-Zabara range and in west by the vast plain of gneissic granitoids which are pierced by conspicuous trachyte plugs (e.g. Gabal Hamrt Salma and Gabal El Nuhud). The maximum width of this antiform is $17 \mathrm{Km}$. Hashad (1990) interpreted the granitic gneisses at the core of domes as 
gneissic granitic intrusions. They named the rock assemblage above the core granite and below the psammitic gneiss as a metamorphosed and deformed ophiolitic mélange assemblage, whereas the psammitic gneiss as a metamorphosed sedimentary unit of a quartozo-feldspathic composition. Several models have been postulated to explain the WHC four tectonic models were proposed to decipher their origin: (1) development of fault-bend fold "antiformal stacks" (e.g.Hafafit domal structure; Greiling et al.,1988a), (2) orogen-parallel crustal extension (e.g. HaFafit, Sibai and Meatiq domal structures; Wallbrecher et al., 1993; Fritz et al., 1996, 2002; Bregar et al., 2002; Loizenbauer et al., 2001; Abdel Wahed, 2008; Khudeir et al., 2008), (3) emplacement within regional domal structures (Ibrahim and Cosgrove, 2001) followed by extension parallel to their fold axes (e.g. Sibai dome, Fowler et al., 2007), and (4) interpreted the WHC as a result of fold interference patterns involving multiply deformed sheath folds (Fowler and El Kalioubi, 2002). The domal structure (WHC) represents the largest antiformal structures in the Nubian Shield. It is considered as one of spectacular structures in the Eastern Desert, but its structural history has not been entirely clarified. The WHC has been subdivided into five separated gneissic domes (labeled A-E core gneisses; of various aerial extends (El Ramly and Greiling, 1988). El Bahariya and Abd El Wahed (2003) considered the granitoid cores together with the genetically related foliated metagabbro to represent the oldest rocks in the Hafafit area. The tectonic evolution of the WHC has been interpreted as a result of fold interference paterns involving multiply deformed sheath folds (Fowler and El Kalioubi, 2002) or as aconsequence of tectono-magmatic and tectono-metamorphic processes in an active continental margin tectonic setting (El Bahariya and Abd El Wahed, 2003). The P-T conditions for the different mineral assemblages in order to place some constraints on the petrogenesis of the migmatitic rock association as well as the tectonic processes which accompanied metamorphism and orogenesis (El Bahariya, 2008). The structural characteristics of the northern dome (dome A) of WHC, field descriptions of the dome and surrounding are discussed with emphases to their relations with the overlying Pan-African cover nappes and the bounding ductile shear zones and suggested that the emplacement of gneissic core occurred during accretion of the Pan-African nappes, later strike-slip shear zones of Najd Fault System and the associated Subsidiary shear arrays postdate emplacement of the dome (Shalaby, 2010). Our main aim of this study is to examine the finite strain, variation pattern in gneissic granitoids in five domes of WHC to known tectonic evaluation of this culmination.

\section{Geological Setting}

The present paper deals with the all granitoids that cored domes of the WHC which is bordered by latitudes $24^{\circ} 35^{\prime} 00^{\prime \prime} \mathrm{N}$ and $24^{\circ} 51^{\prime} 00^{\prime \prime} \mathrm{N}$ and longitudes $34^{\circ} 30^{\prime} 00^{\prime \prime} \mathrm{E}$ and $34^{\circ} 45^{\prime} 00^{\prime \prime} \mathrm{E}$. The WHC has been subdivided into five separated gneissic domes (labeled A-E core gneisses; of various aerial extends (El Ramly and Greiling, 1988) (Fig.1a, b). These domes are composed of medium grade gneisses and are separated from the overlying low grade metamorphic rocks by low angle thrust zones. The rock assemblages in Hafafit area could be grouped into two main units which are separated by Nugrus Thrust. The eastern unit (Nugrus unit) is composed mainly of low grade mica-schists and metavolcanics. This unit is associated with remnants of ophiolitic altered ultramafic and metagabbros.The western unit (Hafafit unit) forms Hafafit domes and includes from core to rim. Granite and gneiss of tonalitic and granodiorite composition, banded amphibolites which is is overthrusted by ultramafic rocks, alternating bands of biotite- and hornblende-gneiss and the psammitic gneiss at the rim of the domal structure. In some parts, the amphibolites are associated with metagabbro (Abd El-Naby and Frisch, 2006). Both units have been intruded by undeformed leucogranites, especially along thrust zones. The present contribution describes the microstructural characteristics of the all from north to south of WHC field descriptions of domes and surrounding with relations of Pan-African and the bounding ductile shear zones. The WHC constitutes an elongated folded belt in Southern Eastern Desert that is about 150 square kilometers, trending NW-SE parallel to the orientation of the Najd fault system. It has evolved and was exhumed in close connection with the activity of this shear zone

$\underline{\text { XLVII, No } 2-668}$ 
system. These granitoids domes are white or greyish white since they consist essentially of oligoclase and quartz with some biotite, hornblende and minor orthoclase. Tonalite prevails in the core of the northernmost dome (dome A), where the peripheral zone is strongly foliated and encloses conformable bands of the foliated metagabbro which several hundreds of meters in length. In places, the tonalite is invaded by numerous, thin pegmatite veinlets giving the erroneous impression of migmatites. The outer rim of this core tonalite is highly injected with white pegmatite veins; it acquires a conspicuous white colour which is accentuated by the weathering and kaolinization of oligoclase. At the northern closure of the dome, highly altered, irregularyshaped, small masses of rusty brown serpentinite are enclosed in this outer rim, where they are transformed along the peripheries of the intruding pegmatite veins into fibrous anthophyllite (Rasmy, 1974). Stern and Hedge (1985) gave an age of $680 \mathrm{Ma}$ to these tonalites. Whereas the domes $\mathrm{B}, \mathrm{C}$ and $\mathrm{D}$ formed tonalite to granodiorites, the dome $\mathrm{E}$ with the conspicuous feature of Naslet Maghar is tonalitic.
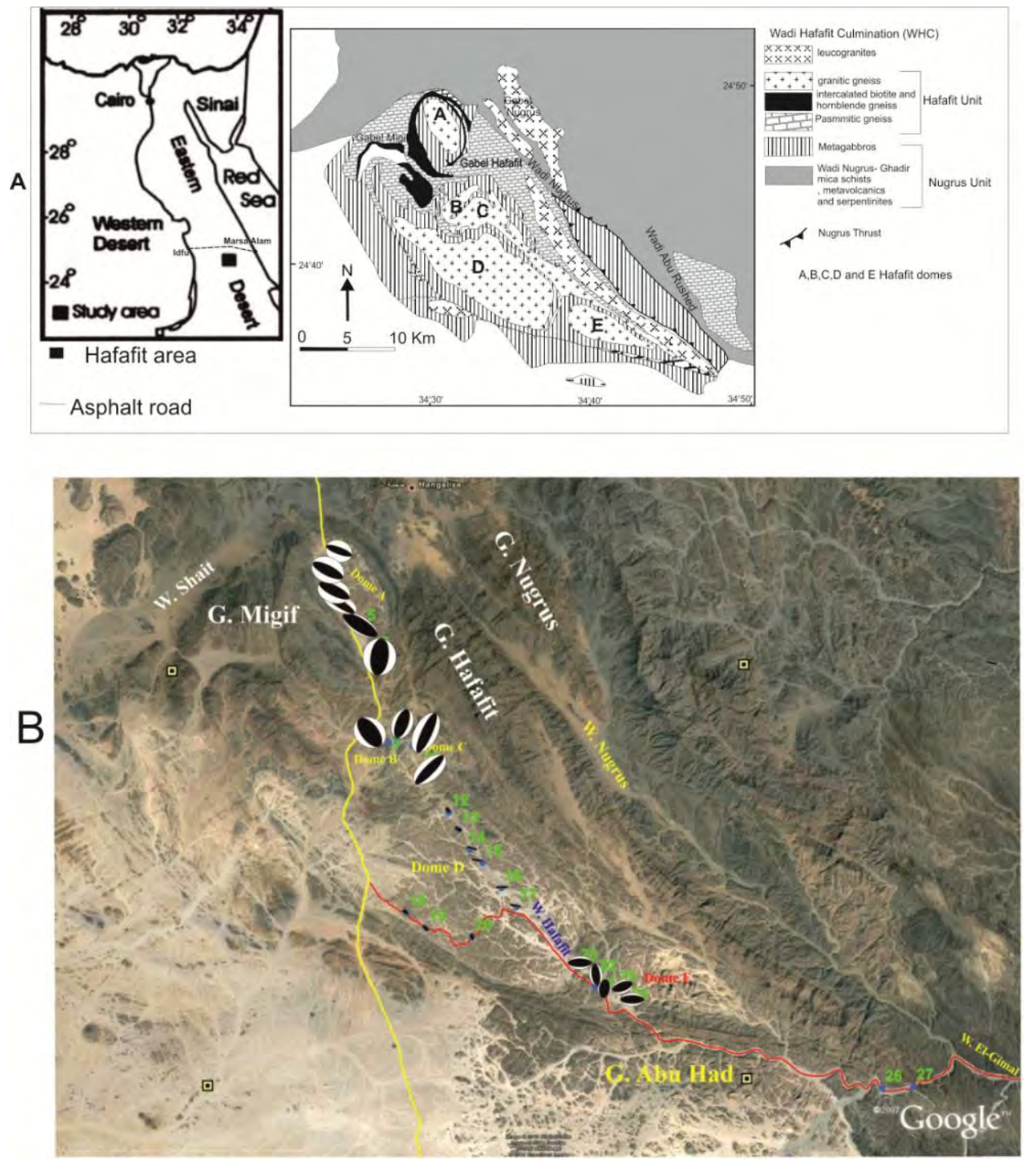

Figure 1 - A- Simplified geological map of Wadi Hafafit area showing major rock types and tectonic structure (modified after El Ramly etal., (1993), B- Photo showing strain ellipsoids in cored granitoids domes of Hafafit.

XLVII, No $2-669$ 


\section{Finite-Strain Analysis}

\subsection{Field Investigations and Sampling:}

24 samples were collected from the Hafafit granitoids domes (for samples localities refer to (Fig. 1b). The Fry and Projection methods used on quartz or feldspar crystal from 6 gneissic tonolite (Dome A), 4 gneissic tonalite and granodiorite (Dome B and C), 9 gneissic tonalite and gneissic granodiorite (Dome D) and 5 gneissic tonalite (Dome E).

Applying the Fry method and projection analysis included: (i) preparation of thin sections along two mutually perpendicular axis (X, Y and Z) subparallel to the $\mathrm{XZ}$ and $\mathrm{YZ}$ principal planes; (ii) take photographs by polarized microscope; and (iii) employ 'fabric 8', program for determining the shape and directions of ellipsoid in each deformation.

\subsection{Techniques Used in Strain Analysis:}

To quantify the finite strain in the Hafafit granitoids domes, feldspars and quartz have been analysed by Fry and Projection techniques (Fry 1979; Ramsay 1967; Ramsay \& Huber 1983; Panozzo, 1984). Two-dimensional strain measurements were made on XY, XZ andYZ sections ( $\mathrm{X} \geq \mathrm{Y} \geq \mathrm{Z}$, finite strain axes) in order to estimate the three dimensional strain geometry. The Fry strains are thought to represent the matrix strain, for Fry analysis, the central points of more than 70 feldspar or quartz grains per section were used to calculate strain. The strain estimates were used to calculate the finite-strain ellipsoid according to the modified least-square technique of Owens (1984).

At first the three principal strain directions $X, Y$ and $Z$ have to be determined ( $X \geq Y \geq Z$; Principal strain axes). For this purpose, the rock sample is cut parallel to lineation, which represents the plane of flattening (XZ) at the maximum extension direction $\mathrm{X}$, which are normal to the foliation and parallel to lineation (XZ). The intermediate strain direction, Y, is defined by its orthogonality with $\mathrm{X}$ and $\mathrm{Z}$, which are normal to foliation and lineation (YZ). After having cut the samples in the Rxz and Ryz directions, Rxy direction has been calculated in accord with the following equation:

$\mathrm{Rxy}=\mathrm{Rxz} / \mathrm{Ryz}$

In addition, the stretches $\mathrm{Sx}, \mathrm{Sy}$ and $\mathrm{Sz}$, which are parallel to principle axes $\mathrm{X}, \mathrm{Y}$ and $\mathrm{Z}$ respectively, enable the following calculation (S) according to (Kassem and Abd El Rahim, 2010).

$\mathrm{Sy}=\sqrt[3]{ }\left(\mathrm{R}_{\mathrm{xz}} / \mathrm{R}_{\mathrm{xy}}^{2}\right)$

$\mathrm{Sx}=\mathrm{R}_{\mathrm{xy}} \times \mathrm{Sy}$

$\mathrm{Sz}=1 /(\mathrm{Sx} \times \mathrm{Sy})$

\subsection{Results of Finite-strain Analysis:}

The sample localities for finite strain analysis are shown in Fig. 1 b, the strain data are summarized in tables 1 and 2 .

\subsubsection{Deformation structures:}

In microstructural investigations were made on thin section cut parallel to the foliation (XY), normal to the foliation and parallel to the lineation (XZ) and normal to the foliation and lineation (YZ).

The granitoids domes of the Hafafit is very heterogeneously deformed in the field, where feldspar grains and quartz show different microstructural features in same dome of granite in thin section are extremely smeared out with aspect ratios in $\mathrm{XZ}$ and $\mathrm{YZ}$ section. The development of normal 


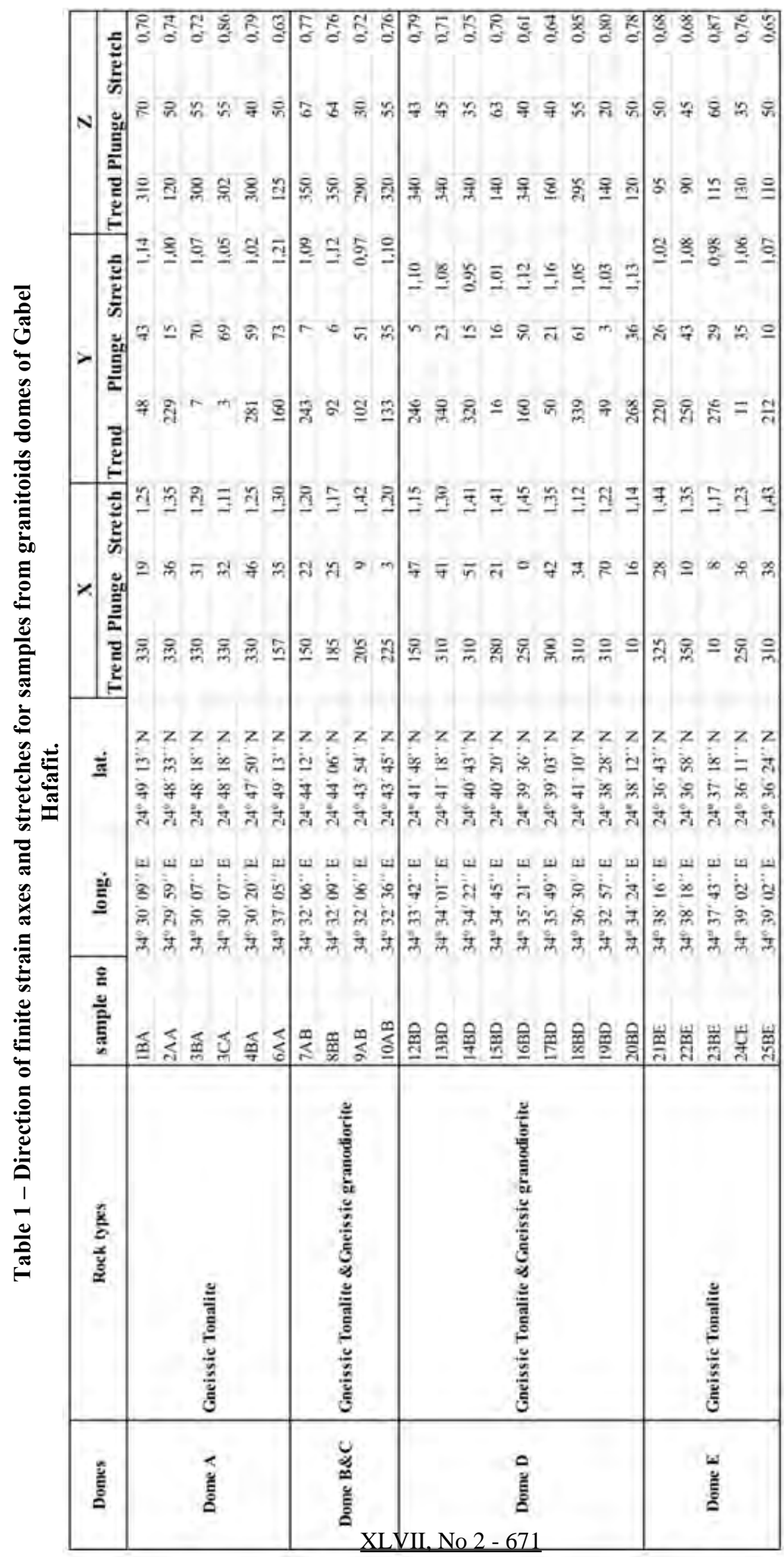


Table 2 - Finite strain data for samples from granitoids domes of Gabel Hafafit.

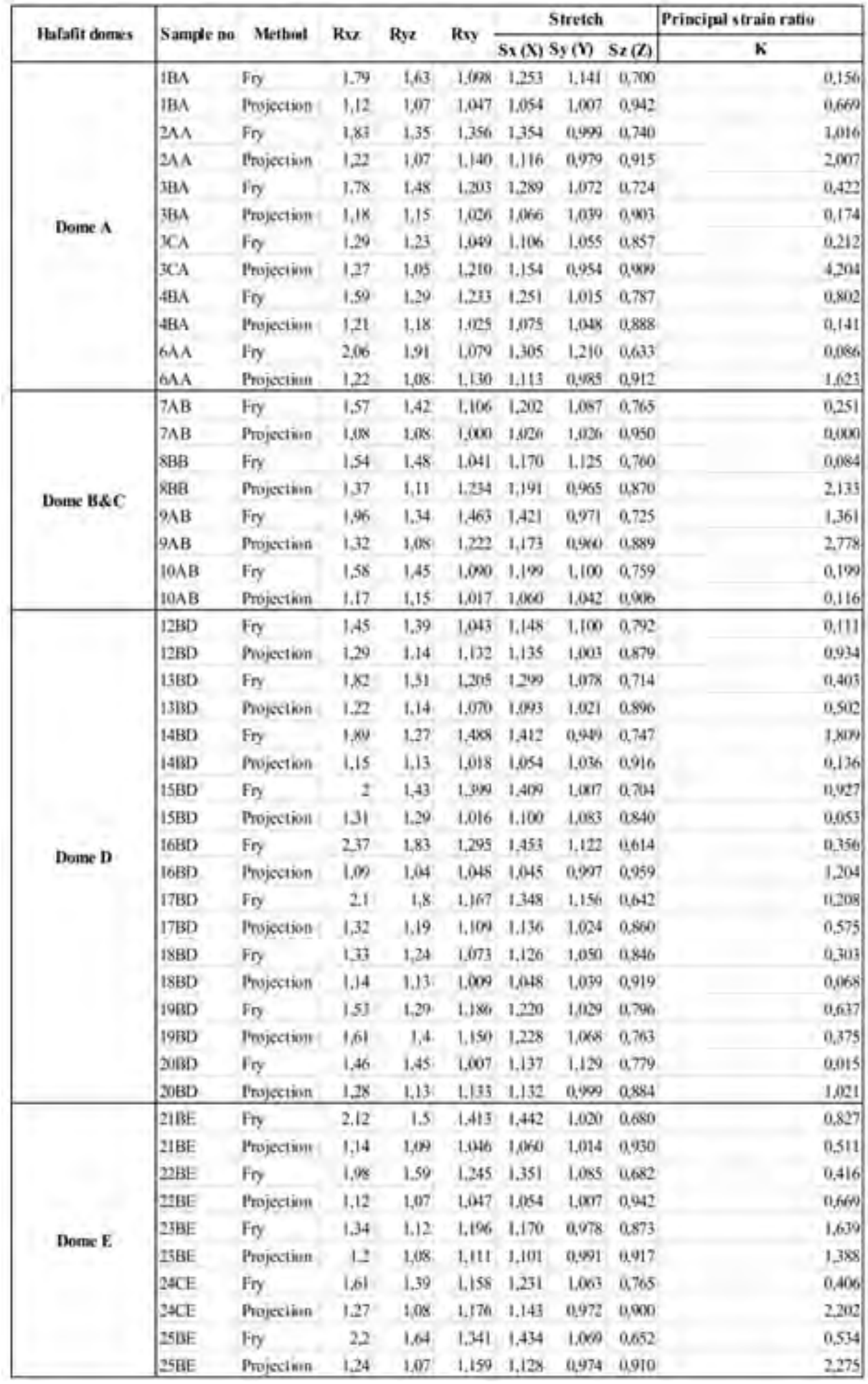

XLVII, No 2-672 


\section{IBAXZ (dome A)}
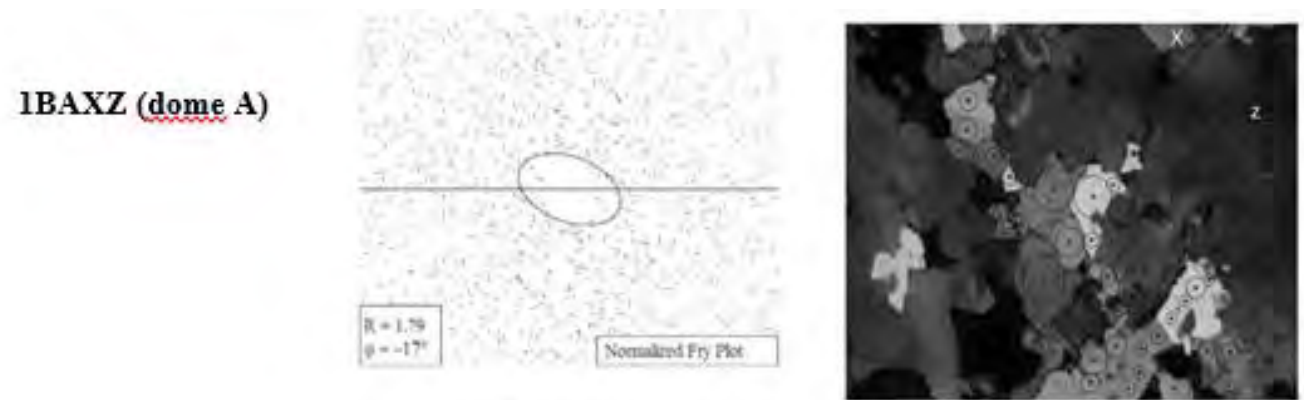

IBAYZ (dome A)

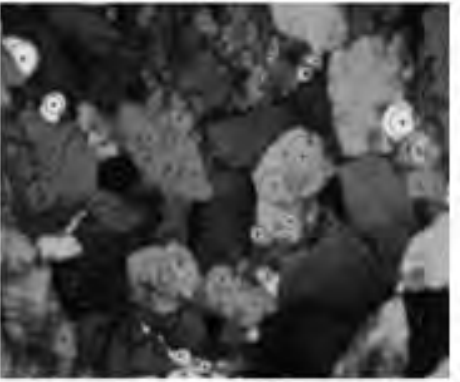

8BBXZ (dome B)
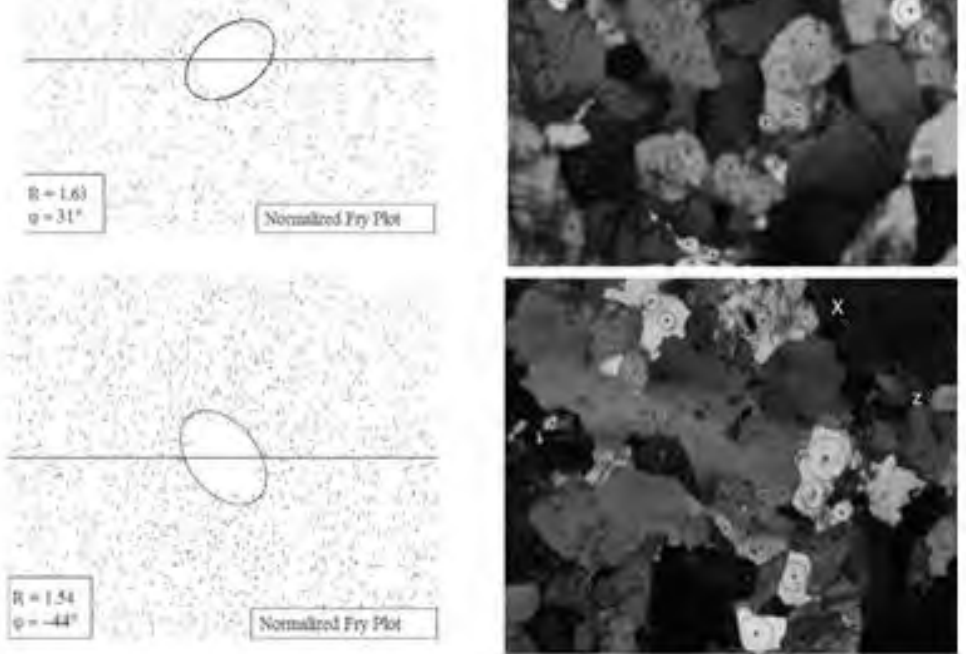

8BBYZ (dome B)
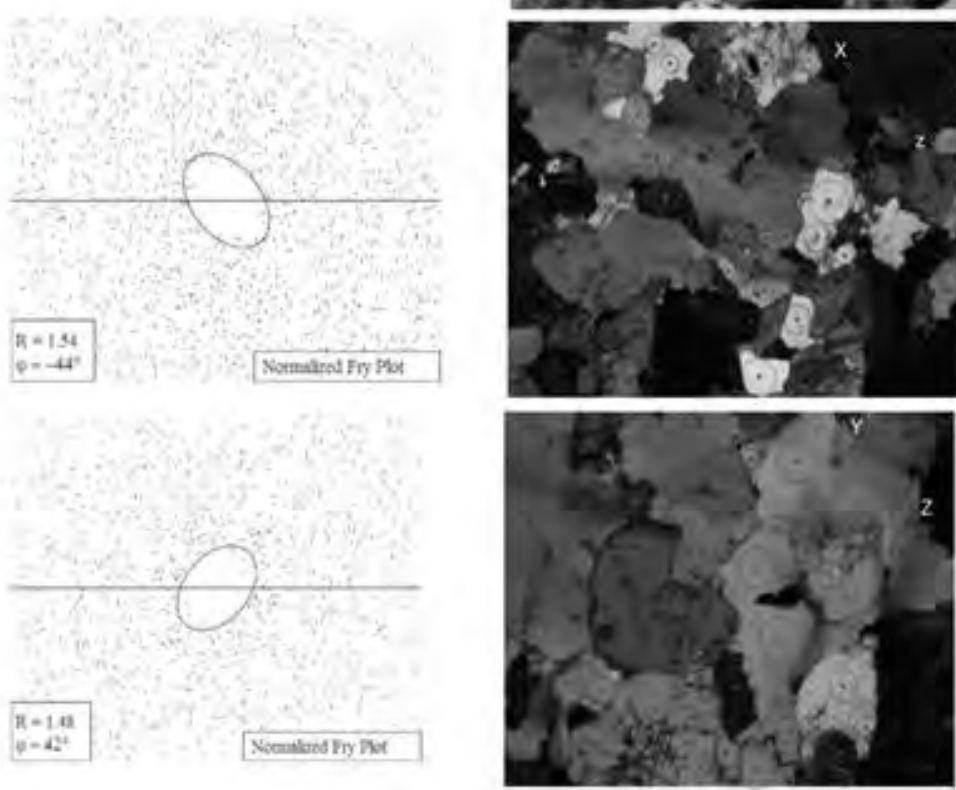

Figure 2 - Fry analysis along $\mathrm{XZ}$ and $\mathrm{YZ}$ principle finite strain planes and original samples surfaces to which fry applied.

tonalite and granodiorite showing hypidomorphic texture to gneissic tonalite and gneissic granodiorite. In the gneissic granite, the main-phase foliation is a gneissic foliated defined by elongated, dynamically recrystallized feldspar and quartz crystals and alignment of biotite and hornblende (Figs.2, 3).

\subsubsection{Magnitudes of Finite Stretches:}

The sample localities for finite strain analysis are shown in (Fig. 1 b). The strain data are summarized in tables $1 \& 2$ shown in a Flinn diagram in (Fig.4), the flinn diagram shows the 

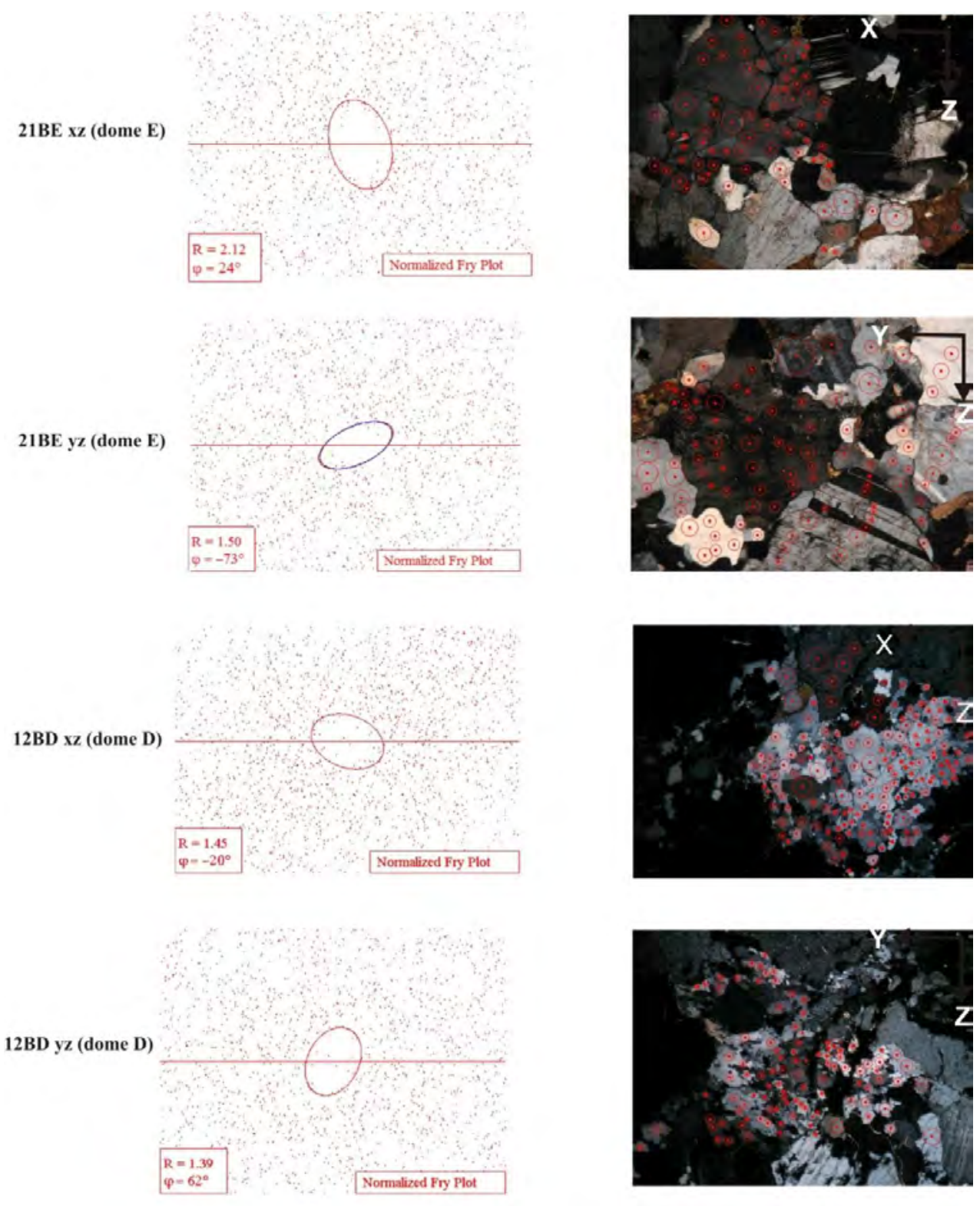

Figure 3 - Fry analysis along $\mathrm{XZ}$ and $\mathrm{YZ}$ principle finite strain planes and original samples surfaces to which fry applied.

relative shapes of the strain ellipsoids, i.e. prolate vs oblate. To infer strain type, i.e constrictional vs flattening, information on volume strain is needed.

As shown in Table 2, Projection strains are not fundamentally different from Fry strains; in some cases, the Fry strains are slightly greater than the projection strains. Therefore, our studied samples show that there was no significant difference in deformation behavior between the biotite and Hornblende matrix and the feldspar-quartz porphyroclasts during the accumulation of finite strain during deformation conditions. Furthermore, finite strain in the gneissic tonalite in dome A is of the same order of magnitude as those from the gneissic tonalite to granodiorite of domes B\&C and the gneissic tonalite dome $\mathrm{E}$ which suggests similar deformation behavior in both lithologies but dome D have another deformation behavior about this domes. In general, the strain ellipsoids in 
domes A, B,C and E have oblate and prolate strain symmetry but the strain ellipsoids in dome D have oblate symmetry only. In the dome (A) The axial ratios in XZ sections range from 1.12 to 2.06 with Sx ranging from 1.05 to 1.35 . The stretches in the $\mathrm{Z}$ direction, Sz range from 0.63 to 0.94 indicating vertical shortening. Sy ranges from 0.95 to 1.20 showing both contraction and extension in this direction.

The strain data verify pronounced heterogeneous deformation of the gneissic tonalite as shown in the field. In dome $\mathrm{B} \& \mathrm{C}$ the axial ratios in $\mathrm{XZ}$ sections range from 1.08 to 1.96 with Sx ranging from 1.025 to 1.42 . The stretches in the $\mathrm{Z}$ direction, $\mathrm{Sz}$ range from 0.72 to 0.95 indicating vertical shortening. Sy ranges from 0.95 to 1.12 showing both contraction and extension in this direction. The strain data verify pronounced heterogeneous deformation of the gneissic tonalite to granodiorite as shown in the field. In the dome (E) the axial ratios in $\mathrm{XZ}$ sections range from 1.12 to 2.20 , with Sx ranging from 1.06 to 1.44 . The stretches in the $\mathrm{Z}$ direction, Sz range from 0.65 to 0.94 indicating vertical shortening. Sy ranges from 0.97 to 1.08 showing both contraction and extension in this direction. The strain data verify pronounced heterogeneous deformation of the gneissic tonalite as shown in the field. In the dome (D)The axial ratios in $\mathrm{XZ}$ sections range from 1.09 to 2.37 with $\mathrm{Sx}$ ranging from 1.045 to 1.45 . The stretches in the $\mathrm{Z}$ direction, $\mathrm{Sz}$ range from 0.61 to 0.95 indicating vertical shortening. Sy ranges from 0.99 to 1.20 showing extension in this direction. The strain data verify pronounced homogeneous deformation of the gneissic tonalite and gneissic granodiorte. All domes A, Band C and E of Hafafit granitoids showing flattening and constricitional strains but dome D showing only flattening this means found different events of deformation.
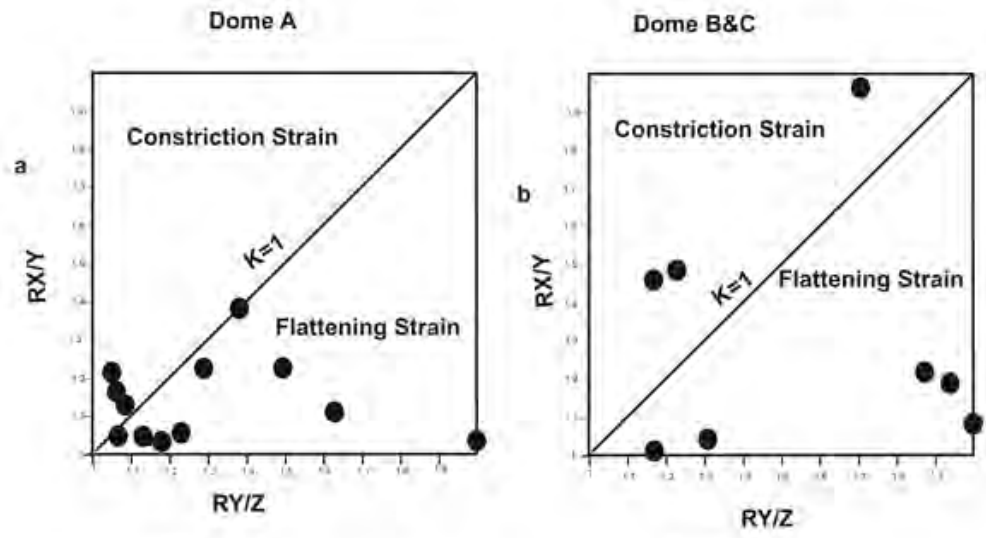

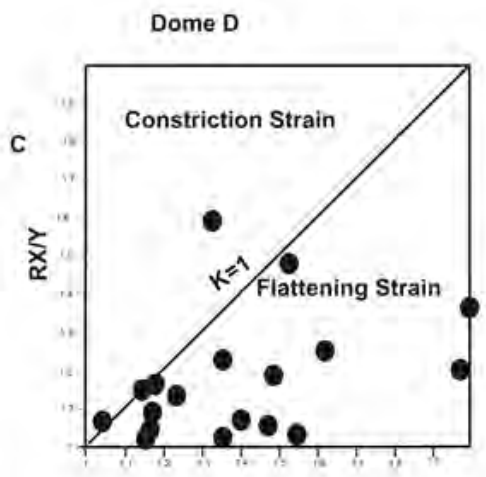

RY/Z

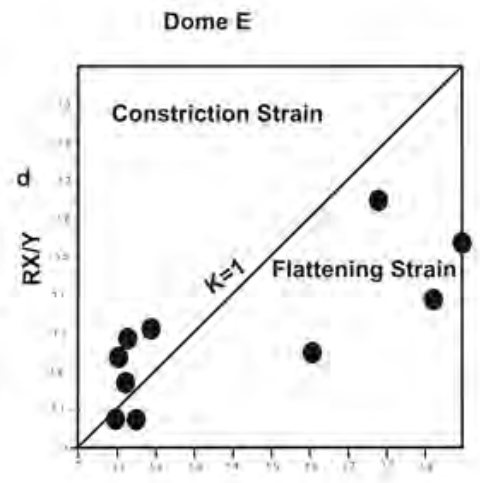

RYIZ

Figure 4 - Flinn diagram showing strain symmetry as obtained by fry and projection methods for Hafafit domes.

XLVII, No 2 - 675 


\section{Discussion}

The data show oblate and prolate symmetry (flattening and constriction strains) in gnessic granitoids of domes A, B, C, E but show oblate syemmetry (flattening strain) only in granitoids of dome $\mathrm{D}$ this indicates that the time of deformation represents the accumulation of ductile to britle not same time and not same deformation events. This means the granitoids domes of Hafafit are subjected to two different stage of deformation. The early stage of deformation the domes A, B, C, $\mathrm{E}$ are affected by more than one deformation event so we observed that the direction of long axis (x) of strain ellipsoid in these gneissic granitoids domes have set W/WSW to N/ENE But granitoids of dome D not affected by this deformation stage. The late stage of deformation all granitoids domes are subjected to general one deformation event so the direction of long axis $(\mathrm{x})$ of strain ellipsoid are common in these domes SE to NW this inductors in cored domes of Hafafit according tectonic evoluation.

Structural observations in WHC show that the culmination is bounded from east and west by two non-parallel left-lateral strike-slip shear zones; namely, Nugrus and El Gemal shear zones, where they intersect south of dome "E" by a pivot and spread away northward, giving rise to the Vgeometry for the whole culmination (Fig. 5). Published structural data in WHC (e.g. Greiling et al., 1988b; Fritz et al., 1996; Fowler and El Kalioubi, 2002; El Naby et al., 2008; Fowler and Osman, 2009; Shalaby, 2010) elucidate:

1. Northwestward tectonic transportation on thrust zones with gradual decrease of shortening across the culmination from south to north, which is indicated by stronger buckling in dome "E" at the pivot and weak buckling in dome "A" northward. Fabrics in cross-sections parallel to stretching lineation show evidences of northwestward ductile stretching involved within gneissic bands especially in domes located further north.

2. Opposite to pivot and especially north of zone between domes " $A$ " and "B", ductile normal shears are frequent, dipping mostly shallowly to NW. These extensional fabrics are reactivated into brittle normal faults of regional extend. (e.g. Shait normal fault)

3. The northern area is intensively crossed by roughly $\mathrm{E}-\mathrm{W}$ trending dykes that rather disappear southward.

4. The dome "B" and "C" is crossed by N-S trending left-lateral strike-slip fault. Displacement on this fault is fading towards zero at dome "D".

5. Late -orogenic extension and crustal thining that controlled by the Najd transform faults that resulted in exhumation of the Hafafit domes through acombination of transpression and lateral extrusion.

\section{Conclusions}

The strain analysis of the deformation in WHC domes south central Eastern Desert of Egypt indicates that ductile deformation show oblate and prolate symmetry (flattening and constriction strains) in gnessic granitoids of WHC domes A, B, C, E and show oblate syemmetry (flattening strain) only in granitoids of dome D. The oblate symmetry (flattening) on all domes due to late orogenic extension and crustal thining associated the Najd transform fault that resulted exhumation of the WHC domes, The domes A, B, C and E show prolate symmetry (constriction strains for this reasons:

1. Dome A sheared with Shait-Nugrus Shear zone (SNSZ) after post arc collision structure (Fowler and Osman, 2009).

2. Dome $\mathrm{B} \& \mathrm{C}$ shows constriction strain becouse more complex patterns of superimposed interference folds and sheared with Shait-Nugrus Shear zone (SNSZ) (Fowler and El Kalioubi, 2002).

3. Dome $\mathrm{E}$ is indicated by stronger buckling in dome "E" at the pivot of two shear zones (Nugrus and El Gemal shear zones).

$\underline{\text { XLVII, No } 2-676}$ 


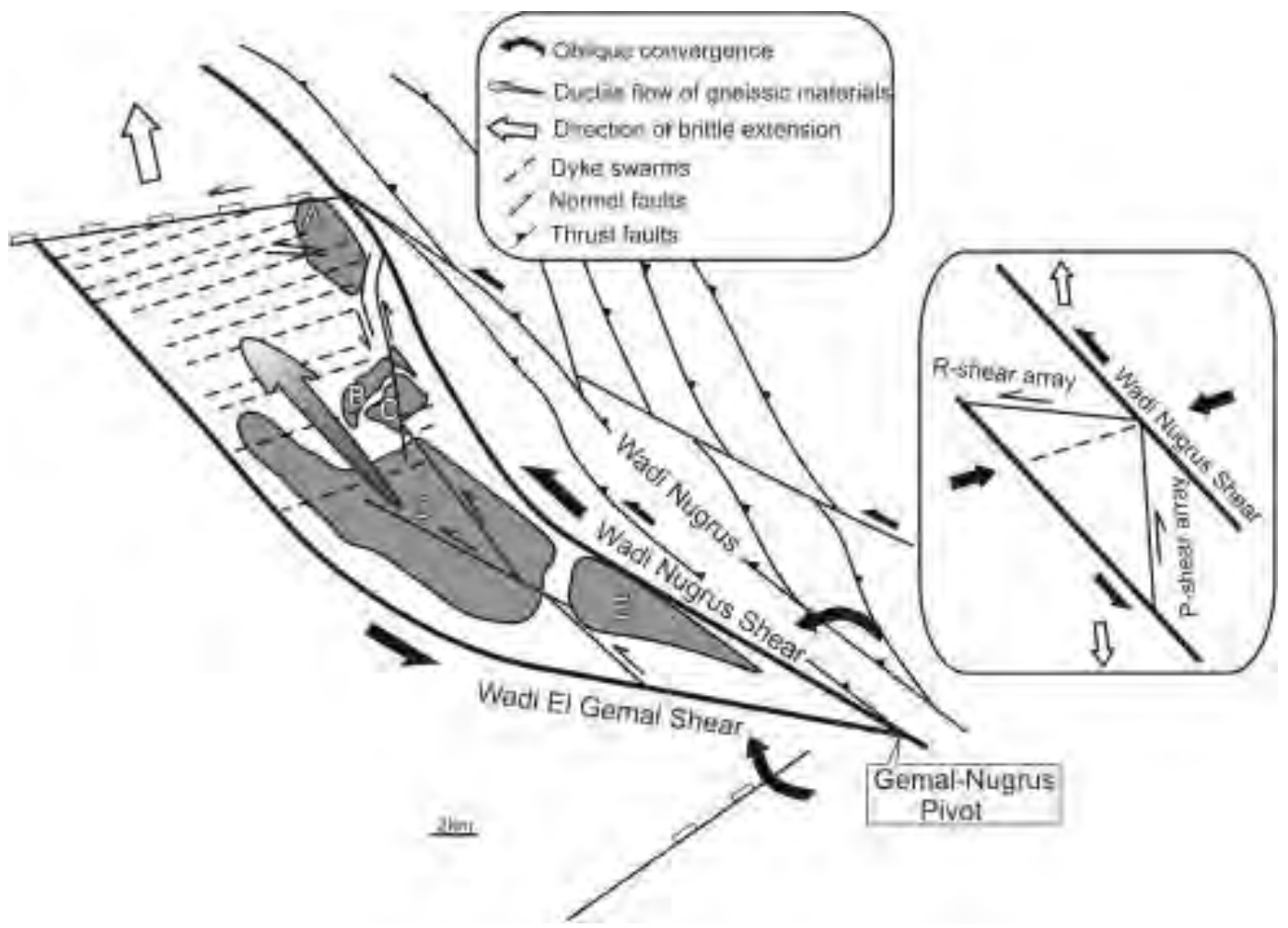

Figure 5 - Simplified structural map for the WHC, collected from landsat images and different literatures (e.g. Greiling et al., 1988b and Fritz et al., 1996; Fowler and El Kalioubi, 2002, Fowler and Osman, 2009 and Shalaby, 2010) The V-geometry for the whole culmination is formed with intersection of two non-parallel left-lateral strike-slip shear zones (Nugrus and El Gemal shear zones) at a pivot, located south of dome "E", while they spread away northward. Stronger domal buckling close to the pivot and weak buckling further north, northwestward ductile stretching in gneissic domes located further north with development of early ductile, later brittle, Sha'it normal faults, the frequent distribution of $E-W$ trending dykes to north and their rather disappear southward, are structural elements that satisfy the synthetic component of the scissor-like deformation model described by Fowler and Osman (2001). In this model, exhumation of Hafafit gneisses is expected to be accomplished by Late -orogenic extension and crustal thining that controlled by the Najd transform faults that resulted in exhumation of the Hafafit domes through a combination of transpression and lateral extrusion.

\section{Acknowledgments}

Our thanks are due to Greece Scholarships Foundation (IKY) for supporting the doctoral studies in Aristotle University Thessaloniki (Greece) our thanks are also Professor Mohamed Abdel Wahed (Tanta University) for helping me in field work.

\section{References}

Abd El-Naby H. and Frisch W. 2006. Geochemical constraints from the Hafafit Metamorphic Complex (HMC): evidence of Neoproterozoic back-arc basin development in the central Eastern Desert of Egypt, Journal of African Earth Science, 45, 173-186. 
Abdel Wahed M. 2008. Thrusting and transpressional shearing in the Pan-African nappe southwest El-Sibai core complex, Central Eastern Desert, Egypt, Journal of African Earth Science, 50, 16-36.

Bregar M., Bauernhofer A., Pelz K., Kloetzli U., Fritz H. and Neumayr P. 2002. A late neoproterozoic magmatic core complex in the Eastern Desert of Egypt; emplacement of granitoids in a wrenchtectonic setting, Precambrian Research, 118, 59-82.

El Bahariya G. A. and Abd El-Wahed M. A. 2003. Petrology, mineral chemistry and tectonic evolution of the northern part of Wadi Hafafit Area, Eastern Desert, Egypt, The 3rd international Conference on the Geology of Africa, Assiut, Egypt, 2, 201-231.

El Bahariya G.A. 2008. Geology and petrology of neoproterozoic syntectonic anatectic migmatites around Wadi abu Higlig, Hafafit region, Eastern Desert, Egypt, Egyptian Journal of Geology, 52, 25-54.

El Ramly M.F. and Greiling R. 1988. Wadi Hafafit Area- 1:100.000 Geology map, Technische Fachhoochschule, Berlin.

El-Ramly M.F., Greiling R., Kröner A. and Rashwan A.A.A. 1984. On the tectonic evolution of the Wadi Hafafit area and environs, Eastern Desert of Egypt, Bulletin of the Faculty of Science, King Abdulaziz University, 6,113-126.

El Ramly M.F., Greiling R.O., Rashwan A.A. and Rasmy A.H. 1993. Explanatory note to accompany the geological and structural maps of Wadi Hafafit area, Eastern Desert of Egypt, Geological Survey of Egypt, Paper No. 68.

Fowler A. and El Kalioubi B. 2002. The Migif-Hafafit gneissic complex of the Egyptian Eastern Desert: fold interference patterns involving multiply deformed sheathfolds, Tectonophysics, $346,247-275$.

Fowler A.R., Khamees H. and Dowidar H. 2007. El Sibai gneissic complex, Central Eastern Desert, Egypt: Folded nappes and syn-kinematic gneissic granitoid sheets - not a core complex, Journal of African Earth Sciences, 49(4), 119-135

Fowler T.J. and Osman A.F. 2001. Gneiss-cored interference dome associated with two phases of late Pan-African thrusting in the Central Eastern Desert, Egypt, Precambnan Research, 108, 17-43.

Fritz H., Dalmeyer D.R., Wallbrecher E., Loizenbauer J., Hoinkes G., Neumayr P. and Khudeir A.A. 2002. Neoproterozoic tectonothermal evolution of the Central Eastern Desert, Egypt: a slow velocity tectonic process of core complex exhumation, Journal of African Earth Sciences, 34, 543-576.

Fritz H., Wallbrecher E., Khudier A.A., Abu El Ela F. and Dallmeyer R.D. 1996. Formation of Neoproterozoic metamorphic core complexes during oblique convegence, Eastern Desert, Egypt, Journal of African Earth Sciences, 23, 311-329.

Fry N. 1979. Random point distributions and strain measurement in rocks, Tectonophysics, 60, 806-807.

Greiling R.O., Abdeen M.M., Dardir A.A., El Akhal H., El Ramly M.F., Kamal El Din G.M., Osman A.F., Rashwan A.A., Rice A.H. and Sadek M.F. 1994. A structural synthesis of the Proteorozoic Arabian-Nubian Shield in Egypt, Geologische Runschau, 83, 484-501.

Greiling R.O., Kröner A., El-Ramly M.F. and Rashwan A.A. 1988. Structural relationships between the southern and central parts of the Eastern Desert of Egypt: details of a fold and thrust belt. In: El-Gaby S, Greiling RO (eds) The Pan-African belt of NE Africa and Adjacent Areas. Earth Evolution. Sciences, Vieweg, 121-145.

Habib M. E., Ahmed A.A. and El-Nady O. 1985. Two Orogenies in the Meatiq Area of the central; Eastern Desert, Egypt, Precambrian Research, 30, 83-111.

Hassan M.A.and Hashad A.H. 1990. Precambrian of Egypt. In: Said R (ed) The Geology of Egypt, Balkema, Rotterdam, 201-248.

Ibrahim S. and Cosgrove J. 2001. Structural and tectonic evolution of the Umm Gheig/El-Shush region, central Eastern Desert of Egypt, Journal of African Earth Sciences, 33, 199-209.

Kassem M. K. and Abd El Rahim H. 2010. Finite-strain analysis of metavolcano-sedementry rocks at Gabel El Mayet area, Eastern Desert, Egypt, Journal of African Earth Sciences, 58, 321-330. 
Khudeir A., Abu El-Rus M., El-Gaby S., El-Nady O. and Bishara W. 2008. Sr-Nd isotopes and geochemistry of the infrastructural rocks in the Meatiq and Hafafit core complexes, Eastern Desert, Egypt: evidence for involvement of pre-Neoproterozoic crust in the growth of Arabian, Nubian Shield Island Arc, 17, 90-108

Owens W. H. 1984. The calculation of a best-fit ellipsoid from elliptical sections on arbitrarily oriented planes, Journal of Structural Geology, 6, 571-578.

Panozzo R., 1984. Two dimensional strains from orentation of lines in aplane, Journal of Structural Geology, 6, 215-221.

Ramsay J.G. 1967. Folding and fracturing of rocks, McGraw-Hill, New York.

Ramsay J.G. and Huber M.I. 1983. The techniques of modern structural geology, v. 1, Strain Analysis, Academic, New York, 307.

Rasmy A.H. 1974. Petrological, mineralogical and genetic studies of the Hafafit pegmatites and related mineralization, Ph.D thesis, Faculty of Science Ain Shams Univ., Cairo.

Shalaby A. 2010. The northern dome of Wadi Hafafit culmination, Eastern Desert, Egypt. Structural setting in tectonic framework of a scissor-like wrench corridor, Journal of African Earth Science.

Stern R.J. and Hedge C.E. 1985. Geochronologic and isotopic constraints on Late Precambrian crustal evolution in the Eastern Desert of Egypt, American Journal of Sciences, 28, 97-127.

Wallbrecher E., Fritz H., Khudeir A.A. and Farahat F. 1993. Kinematics of Pan-African thrusting and extension in Egypt. In: Thorweihe U, Schandehneier H (eds) Geoscientific Research in Northeast Africa, Balkema, Rotterdam, 27-30. 